\title{
Study on 3D Micro-pore Structure Characteristics of Dolomite Reservoir with Different Scales
}

\author{
Congjiao Xie* and Zhenliang Guan \\ Key Laboratory of Tectonics and Petroleum Resources, China University of Geosciences, Ministry of Education, Wuhan, Hubei, China
}

Submission: October 23, 2019; Published: November 01, 2019

*Corresponding author: Congjiao Xie, Key Laboratory of Tectonics and Petroleum Resources, China University of Geosciences, Ministry of Education, Wuhan, Hubei, China

\begin{abstract}
Tight dolomite reservoir microscopic pore structure characteristic is the key factor to explore this kind of unconventional reservoirs. In this paper, 3D high resolution reservoir characterization technique based on Micro - CT imaging, constant-rate mercury injection, high-pressure mercury injection and low-temperature nitrogen adsorption test technology are applied to study the micro-pore textures characteristics for T12C well Tanggu, Dagang oilfield with different scales. Through Micro-CT scan imaging, image processing, 3D visualization, porosity calculation and pore structure parameter reconstruction, it is concluded that Micro - CT imaging can directly reflect the changes of fracture and pore in 3D space; the pore radius distribution are close to the result of constant-rate mercury injection and high-pressure mercury injection method, wider than that of low-temperature nitrogen adsorption test; compared with these three methods, the porosity range obtained by Micro - CT imaging technology is slightly narrow. Thus, in order to be effective, comprehensive and accurate to characterize different scales microscopic pore structure characteristics of tight dolomite reservoir, it is better to integrate these four methods.
\end{abstract}

Keywords: Micro-CT imaging; 3D visualization; Tight dolomite reservoir; Micro pore Texture; Different scale

\section{Introduction}

$\mathrm{S}_{3}{ }^{5}$ interval of Tanggu oilfield, located in Dagang, Tianjin, is a tight oil reservoir, with the character of abnormal pressure, low porosity and permeability. Dolomite, argillaceous dolomite is dominant within the reservoirs; reservoir space is the rock cracks and pores; low natural productivity, taking advantage of fracturing can improve productivity. The character of this kind of special lithologic body is poor reservoir property, small pore throat radius, the high displacement pressure, which seriously restricts fluid flow and development, so new ways and technologies should be applied in the fine reservoir description, to determine the micro pore structure of reservoir, finally support the oilfield development. Using the Micro - CT technology to carry on 3D scan and reconstruction for 5 cores in $\mathrm{T} 12 \mathrm{C}$ well, combined with constant-rate mercury injection, high-pressure mercury injection and low-temperature nitrogen adsorption test technology, the paper analysis the microscopic pore structure of dolomite reservoir in Tanggu oilfield.

\section{The Technology of Micro - CT and the Reconstruction} of Pore

\section{Sample Design}

The samples are derived from dolomite and argillaceous dolomite reservoir cores of $\mathrm{S}_{3}{ }^{5}$ interval of Tanggu oil field in T12C
Dagang oilfield, before CT scanning and microscopic pore structure analysis, first using the microscope to identify the rock section and determine porosity, permeability. The identification of thin section shows that the samples are consist of ankerite, feldspar, zeolite and pyrite, with some sections developing fracture, solution pores, and intergranular hole, and other region's pore poor. Use the AP - 608 automatic pressure analysis of porosity and permeability tester produced by Coretest company in America to analysis, the porosity of the samples is $12.3 \%$, and the permeability is $2.24 \times 10^{-3} \mu \mathrm{m}^{2}$. The sample is processed into a $2-7 \mathrm{~mm}$ diameter subsamples, then carry on high resolution Micro-CT scan, the corresponding pixel size is $4.95 \mathrm{~mm}$, maximum resolution of $0.5 \mathrm{~mm}$.

\section{CT Imaging}

In order to ensure that 3D pore structure analysis result is consistent with the actual pore structure, image resolution should be as high as possible. According to the need of this research, the instrument for CT scanning the sample of dolomite core is the type 1172 Micro-CT, produced by Belgian Skyscan company, with X-ray source voltage $20 \sim 80 \mathrm{KV}$, electric current $0 \sim 100 \mu \mathrm{A}$, diameter of focus $\leq 8 \mu \mathrm{m}$, the power of tube $\geq 8 \mathrm{~W}$, the highest resolution $\leq 0.5 \mu \mathrm{m} / 5 \mu \mathrm{m}$ ( $10 \% \mathrm{MFT}$, isotropic). X-ray detector can obtain CT image of $4000 \times 2600$ pixels, the depth of each pixel is 16 . The an- 
gular accuracy of the sample turn table is $0.001^{\circ}$; the Pixel resolution of dolomite CT image is $5 \mu \mathrm{m}$ (Figure 1 ). The advantage of the instrument is that which can reconstruct 2D and 3D images and be saved in the form of animation and photo, define any shape of the interest area, support 3D image segmentation and stitching. Observed from (Figure 1), the pore of sample M1 to M2 develops differently. The facture of sample M1 develops well, with big pore in some regions; the sample M2 is tight, have strong heterogeneity, with big pore in some regions; the sample M3 contains flower mineral, develops dissolved pore; the lithology of the sample M4 is dense, with good development of mineral and strong heterogeneity; the sample M5 is homogeneous, poor mineral.

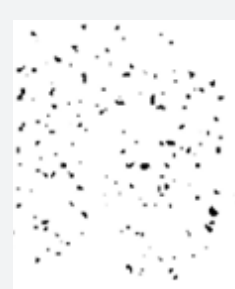

M1

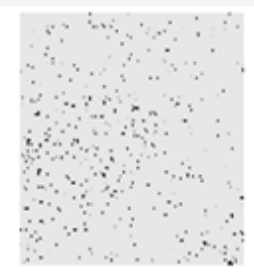

$\mathrm{M} 2$

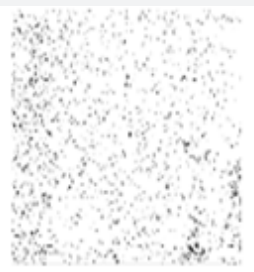

M3

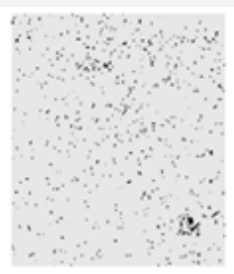

M4

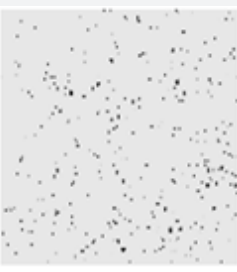

M5

Figure 1: Five Samples of Micro-CT Imaging from M1 to M5.

\section{D visualization}
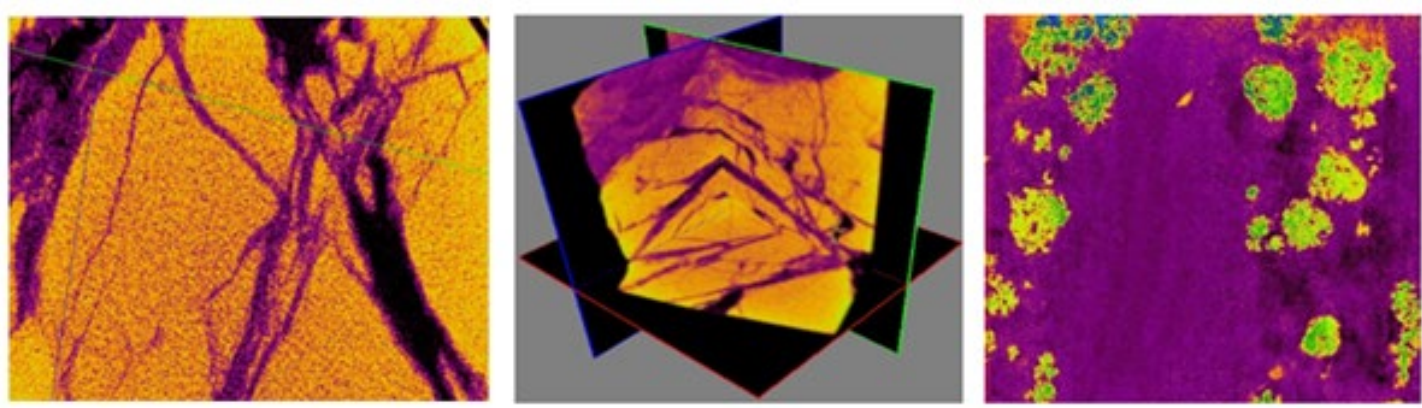

Figure 2: Any Slice of Micro-CT Image after Reconstruction.
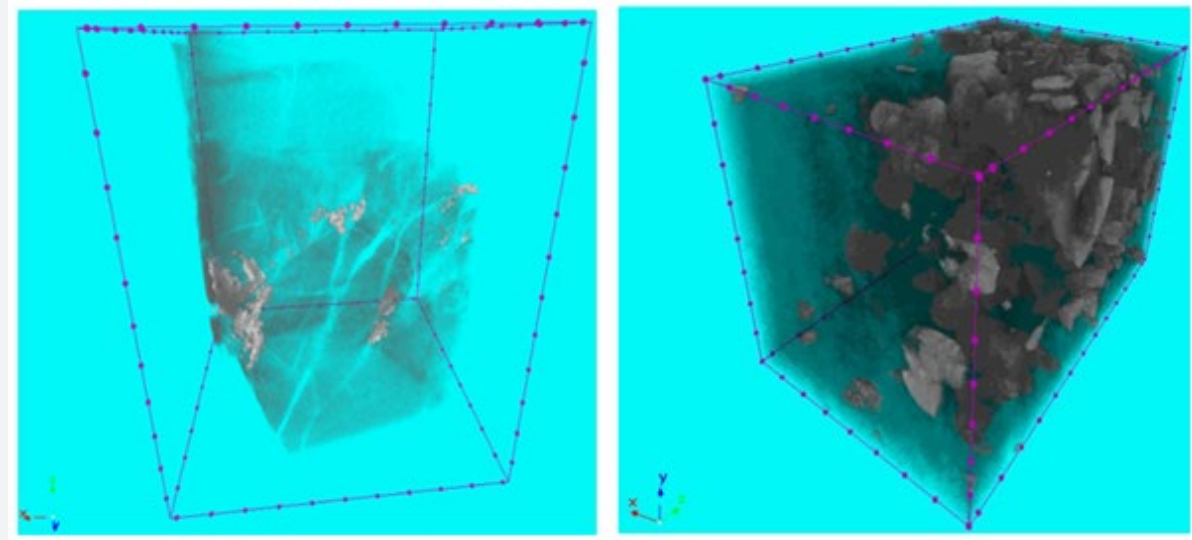

Figure 3: The 3D Micro-CT Reconstruction Visualization Image of Dolomite Core.

According to the scanning image, take advantage of VG Studio MAX2.0 software to render solid phase (Figure 2) and pore phase 3D visualization image (Figure 3) of dolomite subsample. As depicts in Figure 2, the sample obtained from T12C well have good quality of fracture, with dissolved pore and inter crystalline pore as the main reservoir space, narrow throat between pores, small coordination number. Through the software, any slice can be made into 3D visualization image, then display pore space in any direction, thus we can know the sample's fracture morphology diversity, the sizes. Mineral particles in two of five samples, clear, in form of preserved egg's surface, are analcime after microscopic identification and elemental chemical analysis. Dissolution pore developed well within the mineral, and later was filled by outside material. Compared with injection experiment and transmission 
electron microscopy, Scanning Electron Microscopy (SEM) and other traditional experimental analysis method, through the establishment of three-dimensional visualization images of the rock pore structure, we can be more intuitive to study pore space dis- tribution of reservoir rock, especially the pore connectivity, then use statistics of pore and throat, further study the distribution and connectivity of microscopic pore in the three dimensional space within the core.

\section{The reconstruction of pore structure parameters}

Table 1: The Pore Structure Parameters of 5 Samples Scanned by Micro-CT.

\begin{tabular}{|c|c|c|c|c|c|c|c|c|c|}
\hline Sample & Range1 $(\mu \mathrm{m})$ & $\begin{array}{c}\text { Range } 2 \\
(\mu \mathrm{m})\end{array}$ & $\begin{array}{c}\text { Range } 3 \\
(\mu \mathrm{m})\end{array}$ & $\begin{array}{c}\text { Range } 4 \\
(\mu \mathrm{m})\end{array}$ & $\begin{array}{c}\text { Range } 5 \\
(\mu \mathrm{m})\end{array}$ & $\begin{array}{c}\text { Range } 6 \\
(\mu \mathrm{m})\end{array}$ & $\begin{array}{c}\text { Total area } \\
\left(\mu \mathrm{m}^{\wedge} 2\right)\end{array}$ & Porosity (\%) & $\begin{array}{l}\text { Mean diame- } \\
\text { ter }(\mu \mathrm{m})\end{array}$ \\
\hline M1 & $0.0-9.9$ & $9.9-19.8$ & $19.8-39.6$ & $39.6-79.3$ & $79.3-158.5$ & $158.5-317.0$ & 52209.1 & 2.39 & 7.37 \\
\hline $\operatorname{area}\left(\mu \mathrm{m}^{\wedge} 2\right)$ & 11850.1 & 30054.6 & 10304.4 & 0 & 0 & 0 & & & \\
\hline M2 & $0.0-9.9$ & 9.9-19.8 & $19.8-39.6$ & $39.6-79.3$ & $79.3-158.5$ & $158.5-317.0$ & 480480.9 & 6.31 & 9.34 \\
\hline $\operatorname{area}\left(\mu \mathrm{m}^{\wedge} 2\right)$ & 52847.1 & 215975.9 & 190288.5 & 16413.5 & 4955.9 & 0 & & & \\
\hline M3 & $0.0-3.0$ & $3.0-6.0$ & $6.0-11.9$ & $11.9-23.9$ & $23.9-47.8$ & $47.8-95.5$ & 271049.8 & 4.41 & 10.8 \\
\hline $\operatorname{area}\left(\mu \mathrm{m}^{\wedge} 2\right)$ & 4664.2 & 25544 & 88127.7 & 97295.7 & 417819 & 13636.2 & & & \\
\hline M4 & $0.0-3.0$ & $3.0-6.0$ & $6.0-11.9$ & $11.9-23.9$ & $23.9-47.8$ & $47.8-95.5$ & 50426.4 & 3.24 & 7.54 \\
\hline $\operatorname{area}\left(\mu \mathrm{m}^{\wedge} 2\right)$ & 1314.1 & 11818.7 & 23762 & 11805.3 & 1726.3 & 0 & & & \\
\hline M5 & $0.0-3.0$ & $3.0-6.0$ & $6.0-11.9$ & $11.9-23.9$ & $23.9-47.8$ & $47.8-95.5$ & 57116.1 & 4.21 & 8.58 \\
\hline $\operatorname{area}\left(\mu \mathrm{m}^{\wedge} 2\right)$ & 1002.6 & 8456.8 & 26689.3 & 18025.8 & 2941.6 & 0 & & & \\
\hline
\end{tabular}

Take advantage of analysis software CTAn to study the parameters of 5 samples which have already been scanned by Micro-CT, pore diameter as shown in Table 1. After binarization processing, the software can also calculate closed porosity, open porosity and total porosity of the image and average pore diameter. As we can see from Table 1, the porosity of 5 samples is between 2.39 and $6.31 \%$, the average porosity is $4.112 \%$. In a single image, minimum porosity was $1.66 \%$, the porosity is $18.26 \%$; the aperture size of 5 samples is between 7.37 and $10.8 \mu \mathrm{m}$, with average pore diameter $8.726 \mu \mathrm{m}$, the minimum aperture $0.96 \mu \mathrm{m}$, the maximum diameter $33.8 \mu \mathrm{m}$ (Table 1 ). The porosity is $2.39-6.31 \%$, calculated by the way of Micro-CT, with the average porosity of $4.112 \%$, significantly less than pressure porosity $(12.3 \%)$ conventionally measured. Because it just calculates matrix porosity of the imag- es scanned by Micro-CT, regardless of the cracks and microcracks, meanwhile, there is no obvious relationship between porosity and aperture. It is consistent with the conclusion proposed by Jingbohefu [1] who also considered it no correlation between porosity and dolomite pore aperture [2]. Figure 4 shows the frequency of the main pore diameter of $\mathrm{T} 12 \mathrm{C}$ well, the pore diameter distribution concentrates among $6-23.9 \mu \mathrm{m}$, also existing above $23.9 \mu \mathrm{m}$, belongs to small-medium aperture scope, with small coordination number. It indicates that the submicron level, micro pore and throat have not been distinguished by Micro-CT. Therefore, when we apply the related statistical result of the pore structure based on Micro-CT images, but also refer to the mercury injection method, low temperature nitrogen isothermal adsorption method, and other test data to verify [3-7].
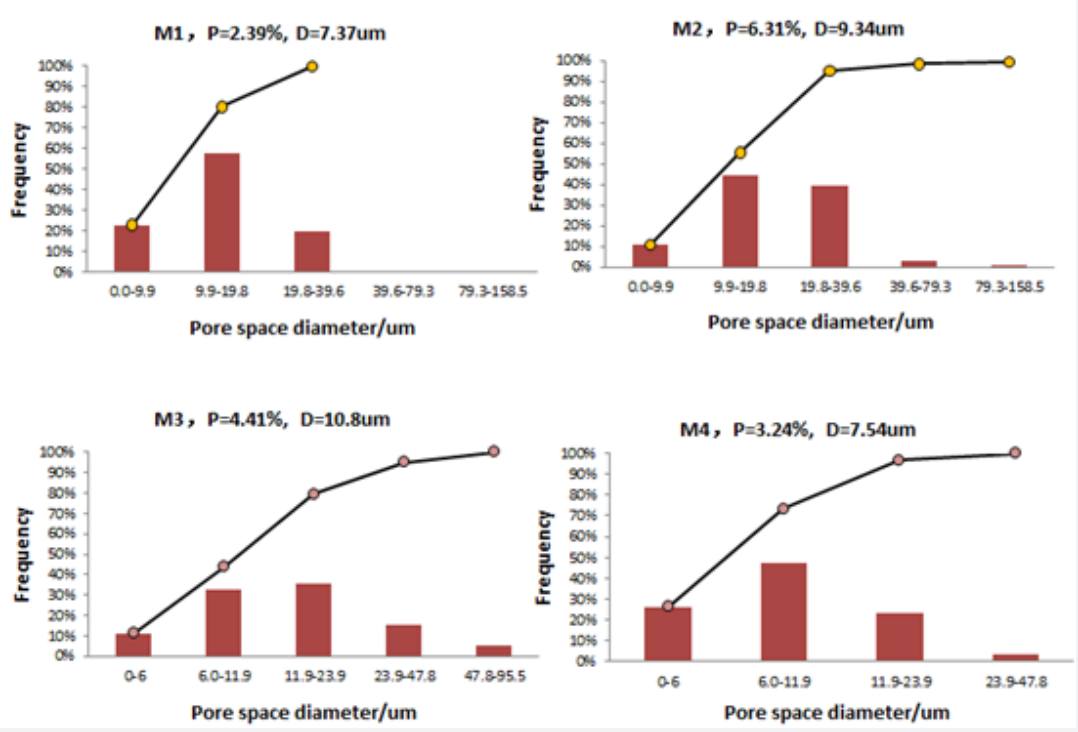

Figure 4: Pore Space Diameter Distribution of T12C Well by Micro-CT. 
Study the Pore Structure based on Constant-rate Mercury Injection

Table 2: 5 Samples Reservoir Characteristic Parameters Examined by Constant-Rate Mercury Injection in T12C Well.

\begin{tabular}{|c|c|c|c|c|c|c|c|c|c|}
\hline Number & $\begin{array}{c}\text { Porosity } \\
/ \%\end{array}$ & $\begin{array}{l}\text { Permeabili- } \\
\text { ty /mD }\end{array}$ & $\begin{array}{l}\text { Average } \\
\text { Throat Ra- } \\
\text { dius/ } \mu \mathrm{m}\end{array}$ & $\begin{array}{c}\text { Main } \\
\text { Throat Ra- } \\
\text { dius/ } \mu \mathrm{m}\end{array}$ & $\begin{array}{c}\text { Max } \\
\text { Throat Ra- } \\
\text { dius } / \mu \mathrm{m}\end{array}$ & $\begin{array}{c}\text { Sorting } \\
\text { Coefficient }\end{array}$ & $\begin{array}{l}\text { Coefficient of } \\
\text { Homogeneity }\end{array}$ & $\begin{array}{l}\text { Relative Sort- } \\
\text { ing Coefficient }\end{array}$ & $\begin{array}{c}\text { Average Pore- } \\
\text { Throat Ratio }\end{array}$ \\
\hline H28-1 & 5.46 & 0.114 & 1.384 & 0.902 & 2.2 & 0.5386 & 0.5812 & 0.3893 & 79.365 \\
\hline H26-2 & 13.554 & 0.241 & 3.855 & 1.866 & 8.5 & 2.388 & 0.3665 & 0.6194 & 86.531 \\
\hline HN1 & 6.132 & 0.535 & 3.275 & 1.451 & 7.6 & 2.1958 & 0.334 & 0.6706 & 57.41 \\
\hline HN3-2 & 7.104 & 0.54 & 3.691 & 1.999 & 6.5 & 1.9408 & 0.4893 & 0.5259 & 72.568 \\
\hline H15-1 & 9.587 & 1.891 & 5.61 & 3.181 & 9.5 & 2.8987 & 0.5117 & 0.5167 & 54.152 \\
\hline
\end{tabular}

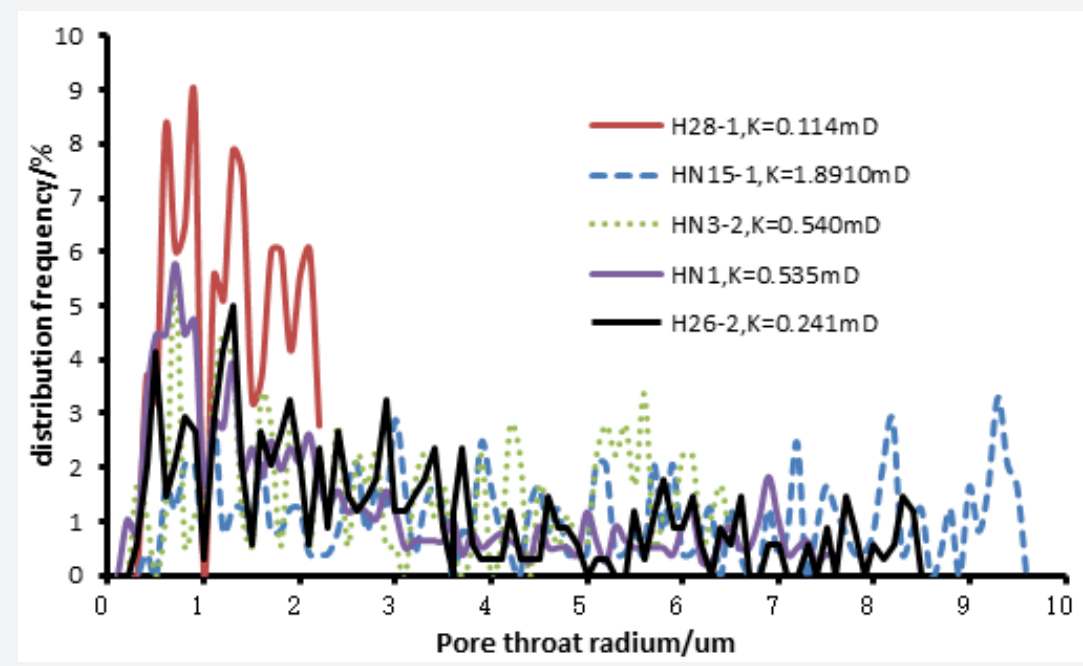

Figure 5: The Distribution of 5 Samples Pore Throat Radium.

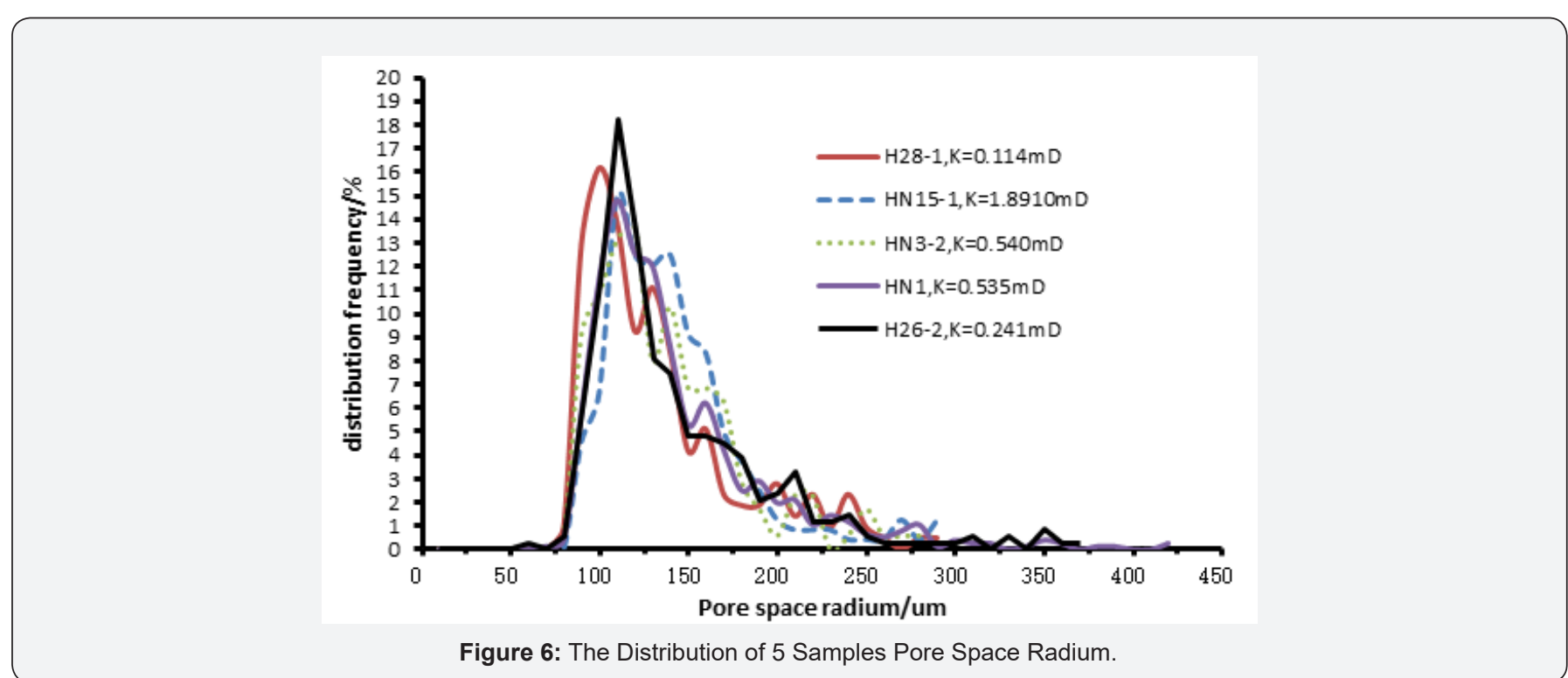

Constant-rate mercury injection is that meniscus of mercury front will generate nature pressure fluctuation when it flows across micro-pore of different shapes by means of constant-rate mercury injection, in the process of quasi static, the pore microstructure is determined. Using ASPE-730 TM (Automated System for Pore Examination) constant-rate mercury injection apparatus to test 5 samples, and their micro homogeneous coefficient, average throat radius, and the contribution of single throat to permeability, relative sorting coefficient and other important characteristic parameters are obtained by ASPEDAS analysis software applying as well [8-10]. The analysis results are shown in Table 2 and Figures 5-7. As we can see from Table 2, the average throat 
radius of 5 samples is $3.563 \mu \mathrm{m}$, which is close to $8.726 \mu \mathrm{m}$ calculated by Micro-CT. As it shown in Figure 5 , the curve is in form of jagged pattern; the throat radius less than $2 \mu \mathrm{m}$ is slightly predominant; the smaller the permeability is, the closer the peak is to the throat area, the distribution frequency becomes smaller from throat to big throat, but the trend is not obvious. The large aperture is mainly concentrated on $80-160 \mu \mathrm{m}$, certainly some pore radius existing in the scope of $160 \sim 400 \mu \mathrm{m}$, consistent with the Micro-CT analysis results(the radius belonging to the range of 79.3 $\sim 158.5 \mu \mathrm{m}$ takes up 10.1\%, Table 1, Figure 1); the difference of radius throat' effect on permeability is big, as Figure 7. Jagged distribution curves impress that the range of the throat distribution of T12C is large, no obvious relationship with permeability. As it shown in constant-rate mercury injection experiment, the pore radius distribution of different permeability core is similar (Figure 6), however, the radius of throat varies widely (Figure 5). It suggests that the throat distribution is the key factor to determine the quality of permeation, if the reservoir permeability is up to the large throat, then the larger the seepage channel, the flow resistance is smaller, the stronger the seepage ability is, the greater the development potential of reservoir; on the contrary, the reservoir permeability is determined by small throat, then the fluid seepage resistance is big, the seepage ability is weak, correspondingly the development of reservoir very difficult ( Figure 7).

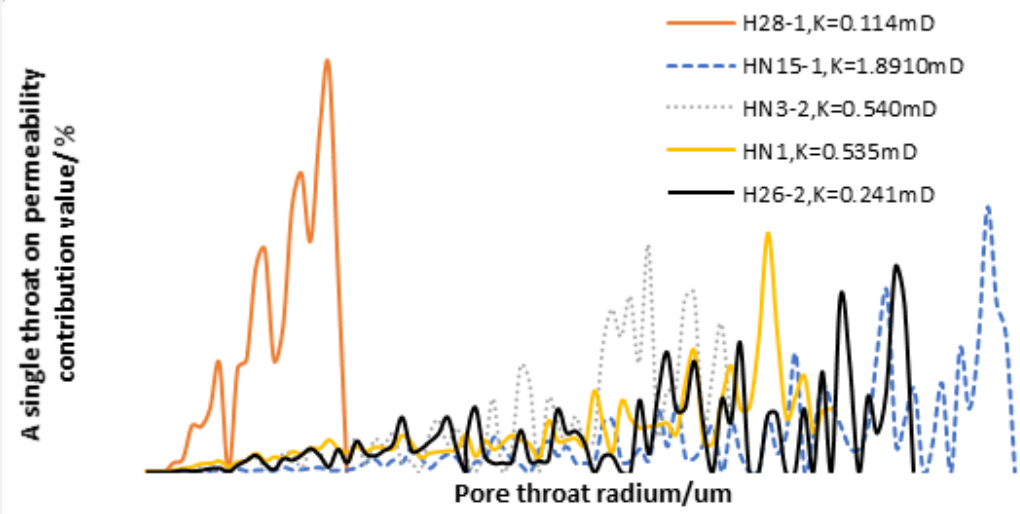

Figure 7: The Distribution of 5 Samples Pore Space Radium.

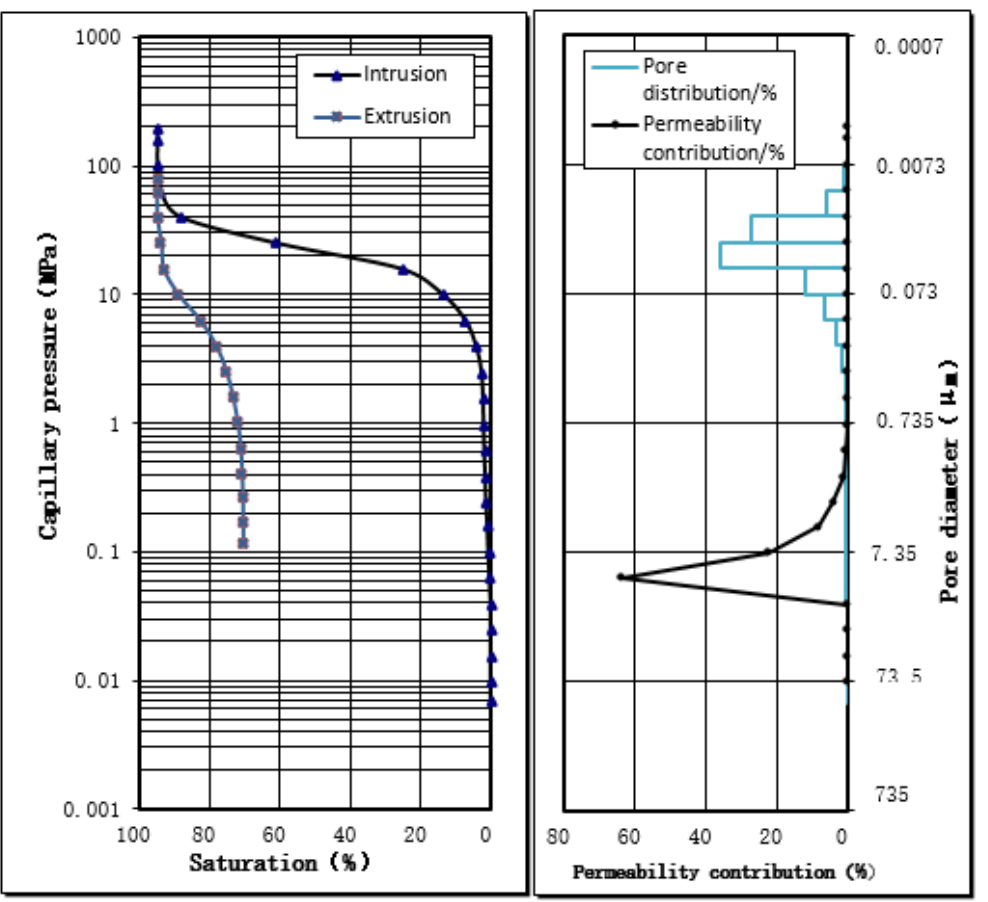

Figure 8: The Capillary Pressure Curve of Sample No. GM4. 
Study the Pore Structure based on High Pressure Mercury Intrusion Method

During the experiment of high pressure mercury intrusion, it will form the pressure curve of the intrusion mercury volume to pressure and the withdraw mercury volume to pressure, the curve of the pore radius to the volume distribution density, the curve of the pore radius to normalized volume distribution curve. High pressure mercury intrusion method is that study the reservoir micro pore structure with the pore throat radius and distribution and other micro pore structure information provided by these curves [11-15]. 5 samples of the T12C well were selected to explore the structure of the pore. The instrument is Autopore IV 9500 high pressure mercury injection apparatus imported from America, the pore diameters distribution ranges from $360 \mu \mathrm{m}$ to $0.005 \mu \mathrm{m}$, the test pressure range is $2 \mathrm{KPa} \sim 228 \mathrm{MPa}$, and the test scope covers the micro-pore, meso pore and macro pore(in accordance with the pore classification standard of the international federation of pure chemistry and applied chemistry (IUPAC), 0 to $2 \mathrm{~nm}$ is micro-pore; 2-50 nanometer is meso pore, more than $50 \mathrm{~nm}$ is macro pore). Table 3 show the test results of 5 samples, Figure 8 displays the capillary pressure curve of GM4 sample. As it shown in the Figure 8 , the mean pore radius is $0.04 \mu \mathrm{m}$, based on the classification standards of IUPAC, GM4 sample belongs to the meso level. From Table 3, the reservoir pore radius distribution ranges from $0.034 \mu \mathrm{m}$ to $3.91 \mu \mathrm{m}$; intrusion $\mathrm{Hg}$ saturation and extrusion Hg efficiency have no obvious relationship with porosity and permeability, but evident with the mean radius and lithology. Nanoscale and sub-micron pore throat of dolomite rock sample is much better than that of argillaceous dolomite rock sample argillaceous dolomite pore structure develops better than that of dolomite [16-20].

\section{The Low-Temperature Nitrogen Adsorption Method to Study the Pore Structure}

Table 3: The Test Result of High-Pressure Mercury Injection.

\begin{tabular}{|c|c|c|c|c|c|c|c|}
\hline No. & Lithology & Porosity /\% & Permeability $/ \mathbf{M d}$ & $\begin{array}{c}\text { Intrusion Hg } \\
\text { Saturation } / \%\end{array}$ & $\begin{array}{c}\text { Extrusion Hg } \\
\text { Efficiency /\% }\end{array}$ & $\begin{array}{c}\text { Max Pore Radi- } \\
\text { us } / \boldsymbol{\mu m}\end{array}$ & $\begin{array}{c}\text { Mean Pore } \\
\text { Radius } / \boldsymbol{\mu m}\end{array}$ \\
\hline G23-1 & dolomite & 12.279 & 0.194 & 1.595 & 1.333 & 5.33 & 3.91 \\
\hline G32-1 & dolomite & 10.945 & 0.003 & 70.305 & 22.102 & 5.32 & 0.091 \\
\hline GM4** & dolomite & 12.131 & 66.0218 & 94.834 & 25.647 & 7.42 & 0.0589 \\
\hline G36-2 & Argillaceous dolomite & 14.749 & 0.136 & 43.627 & 21.216 & 5.21 & 0.034 \\
\hline GM6-2 & Argillaceous dolomite & 14.1691 & 0.0003 & 93.134 & 34.108 & 0.35 & 0.0375 \\
\hline
\end{tabular}

${ }^{*}$ Permeability is Test by the Gas Measured Method.

** Dissolution Pores are Visible with Naked Eyes.

Table 4: The Result of Low-Temperature Nitrogen Adsorption Tests.

\begin{tabular}{|c|c|c|c|c|c|c|c|c|}
\hline No. & Lithology & $\begin{array}{c}\text { Porosity } \\
\text { /\% }\end{array}$ & $\begin{array}{c}\text { Permeabil- } \\
\text { ity /Md }\end{array}$ & $\begin{array}{c}\text { Pore Capaci- } \\
\text { ty /Mm3/G }\end{array}$ & $\begin{array}{c}\text { Average Radius } \\
\text { of Meso-Microp- } \\
\text { oropus / } \mathbf{\mu m}\end{array}$ & $\begin{array}{c}\text { The Porosity of } \\
\text { The Meso-Microp- } \\
\text { oropus /\% }\end{array}$ & $\begin{array}{c}\text { Volume Ratio of } \\
\text { The Meso-Micro- } \\
\text { poropus /\% }\end{array}$ & $\begin{array}{c}\text { S-V /*106/ } \\
\text { M-1 }\end{array}$ \\
\hline D 23-1 & dolomite & 12.279 & 0.027 & 31.84 & 0.00705 & 7.04 & 57.3 & 19.7 \\
\hline D 32-1 & dolomite & 10.945 & 0.0015 & 20.93 & 0.01329 & 4.8 & 43.85 & 7.4 \\
\hline D M5-3 & $\begin{array}{c}\text { Argillaceous } \\
\text { dolomite }\end{array}$ & 13.206 & 0.0022 & 31.55 & 0.02727 & 7.26 & 55 \\
\hline D 36-2 & $\begin{array}{c}\text { Argillaceous } \\
\text { dolomite }\end{array}$ & 14.749 & 0.005 & 20.23 & 0.01409 & 4.35 & 29.52 & 9.4 \\
\hline D N3-2 & $\begin{array}{c}\text { Argillaceous } \\
\text { dolomite }\end{array}$ & 13.332 & 0.049 & 16.57 & 0.01323 & 3.7 & 27.73 & 8.4 \\
\hline
\end{tabular}

** Dissolution Pores are Visible with Naked Eyes.

Low-temperature nitrogen adsorption method is based on physical adsorption principle of nitrogen in solid surface, measured nitrogen adsorption capacity under different relative pressure, drawing the sorption isotherm. It is through BET (Brunauer Emmett Teller) equation or langmiur to calculate monolayer adsorption capacity, to acquire the specific surface area of the sample, then makes use of BJH (Barrot - Joyner Halenda) method to calculate the pore size distribution. This method can detect the aperture distribution range which is $0.00035 \sim 0.1 \mu \mathrm{m}$ nanoscale pore throat, test range of microporous and mesoporous level, the highest accuracy less than $0.05 \mu \mathrm{m}$. Table 4 and Figure 9 show the
5 sample of T12C well low-temperature nitrogen adsorption test result. Pore volume in Table 4 is that the percentage of micro-pore and mesopore volume takes up unit mass rock sample, distribution range of 16.57 to $31.84 \mathrm{~mm}^{3} / \mathrm{g}$, pore volume on average value of $24.22 \mathrm{~mm}^{3} / \mathrm{g}$. In the view of lithology, dolomite and argillaceous dolomite is slightly different: the pore volume of dolomite is between 20.93 and $31.84 \mathrm{~mm}^{3} / \mathrm{g}$, with a mean of $26.38 \mathrm{~mm}^{3} / \mathrm{g}$; pore volume of argillaceous dolomite range from 16.57 to 31.55 $\mathrm{mm}^{3} / \mathrm{g}$, with a mean of $22.78 \mathrm{~mm}^{3} / \mathrm{g}$, slightly less than the pore volume of argillaceous dolomite. It illustrates that dolomite pore space under $0.05 \mu \mathrm{m}$ is larger than that of argillaceous dolomite, 
with fluid flowing difficultly. The average radius of micro-pore and mesopore in Table 4 ranges 0.0071 to $0.027 \mu \mathrm{m}$, dolomite's on average is smaller.

The results are consistent with the conclusion drawn by the high-pressure mercury intrusion method and illustrate that Micro - CT cannot distinguish the micro pore throat of the submicron level inside the core. The porosity of the meso-microporopus is the ratio of meso-microporopus volume to the volume of the core. The porosity of the meso-microporopus of 5 samples in $\mathrm{T} 12 \mathrm{C}$ well ranges from $3.70 \%$ to $7.26 \%$, with the average value of $5.43 \%$, which illustrates that the porosity of $\mathrm{T} 21 \mathrm{C}$ well is low, and the conclusion is highly consistent with the porosity of $2.39-6.31 \%$ and the mean value of $4.112 \%$ measured by the way of Micro-CT. The volume ratio of the meso-microporopus, another parameter in Table 4 , is defined as the ratio of volume of pore, with its radius less than $0.05 \mu \mathrm{m}$, to the total volume of the pore. The volume ratio of the meso-microporopus of the five samples is $27.73-55.0 \%$, and the average value is $42.68 \%$, which implies that about half reservoir space scatters in the pore throat less than $0.05 \mu \mathrm{m}$, resulting in the development difficult. The volume ratio of the meso-microporopus of dolomite ranges $43.85 \%$ to $57.30 \%$, with the average value of $50.58 \%$; the argillaceous dolomite's is $27.73-55.0 \%$, and the mean of $37.42 \%$. Apparently, most of the spatial of dolomite distributes in the pore and throat less than $0.05 \mu \mathrm{m}$, and significantly greater than argillaceous dolomite, therefore, argillaceous dolomite has better development potential than dolomite [21,22].

The S-V, in Table 4, is the ratio of the total surface area to the volume of core sample. The size of S-V is related to the intensity of solid and liquid effect: the greater the S-V is, the more intense the effect of solid and liquid effect is, and the weaker of the capacity of low, more difficult to develop. The S-V of the 5 samples is $0.69-1.97\left(\times 10^{7} / \mathrm{m}^{-1}\right)$ with the average value of $1.04\left(\times 10^{7} / \mathrm{m}^{-1}\right)$. Among them, the S-V of dolomite is in the range of 0.74 to 1.97 $\left(\times 10^{7} / \mathrm{m}^{-1}\right)$, with the mean of $1.36\left(\times 10^{7} / \mathrm{m}^{-1}\right)$; the argillaceous dolomite's ranges from $0.69\left(\times 10^{7} / \mathrm{m}^{-1}\right)$ to $0.94\left(\times 10^{7} / \mathrm{m}^{-1}\right)$, with the mean of $0.82\left(\times 10^{7} / \mathrm{m}^{-1}\right)$.Thus, the solid-liquid effect of dolomite is stronger than argillaceous dolomite, and development difficulty is relatively large [23-25]. As it shown in Figure 9, specific surface test curve of T12C well can be divided into four types (I, II, III, IV) as following:

Type I: The overall state of multi-peak, vertex occurs at the microporous and mesoporous border area, mesoporous area shows a small fluctuation and rises to the similar height with the peak of meso-microporopus (D23-1).

Type II: Microporous interval appears small-scope fluctuation, with local pronounced peaks, as a whole, present the bimodal or many peaks, but the vertices is in the range of mesoporous (D32-1).

Type III: Microporous interval appears small-scope fluctuation, with local pronounced peaks, overall present the bimodal or many peaks, but the vertices in the range of mesoporous (DN3-2).
Type IV: The pores at all levels, gradually increase from small to large, with no obvious jump (DM5-3).

\section{Conclusion}

a) Based on all the above research, it can be concluded as followings:

b) Micro-CT scanning is a good tool to describe the micro-network of pore structure. Pore space, pore throat radius, closed porosity, open porosity and total porosity can be calculated; also coordinate number is estimated as well.

c) Compared with Constant speed mercury intrusion method, High pressure mercury intrusion method and low-temperature nitrogen adsorption method, Micro-CT scanning is most adequately to the $\mathrm{T} 12 \mathrm{C}$ well to study the micro-network of pore structure, especially for the $\mu \mathrm{m}$ size pore scale.

d) The pore space radium distribution of the T12C well range from 6 to $23.9 \mu \mathrm{m}$, moreover more than $23.9 \mu \mathrm{m}$ is well. The mean porosity is $4.1 \%$ that belongs to small scale type of porosity.

e) As a result of constant speed mercury intrusion method, high pressure mercury intrusion method and low-temperature nitrogen adsorption method, argillaceous dolomite has better development potential than that of the dolomite.

\section{References}

1. Jinbohefu (1977) Study on carbonate reservoir physics properties. Society of Petroleum Engineers (SPE) 42(6): 40-46.

2. Wang CC, Yao J, Yang YF, Wang X, JI GS, Gao Y (2013) Structure characteristics analysis of carbonate dual pore digital rock. Journal of China University of Petroleum (Edition of Natural Science) 2: 14.

3. Al-Kharusi AS, Blunt MJ (2007) Network extraction from sandstone and carbonate pore space images. Journal of Petroleum Science and Engineering 56(4): 219-231.

4. Alvaradol FE, Grader AS, Halleck PM (2006) Visualization of two-and three-phase flow in fractures using X-ray computed tomography. Proceedings, SCA International Symposium, Trondheim, Norway, p. 12-16.

5. Arns CH, Bauget F, Limaye A (2005) Pore-scale characterization of carbonates using X-ray microtomography. SPE Journal 10(4): 475-484.

6. Bai B, Zhu Rk, Wu St (2013) Multi-scale method of Nano (Micro)-CT study on microscopic pore structure of tight sandstone of Yanchang Formation Ordos Basin. Petroleum exploration and development 40(3): 354-358.

7. Baldwin CA, Sederman AJ, Mantle MD, Alexander P, Gladden LF (1996) Determination and characterization of the structure of a pore space from 3D volume images. Journal of Colloid and Interface Science 181(1): 79-92.

8. Craze RC (1950) Performance of limestone reservoir. Trams. AIME 189: 287-294

9. Chawla N, Sidhu RS, Ganesh VV (2006) Three-dimensional visualization and microstructure-based modeling of deformation in particle-reinforced composites. Acta Materialia 54(6): 1541-1548.

10. Churcher PL, French PR, Shaw JC (1991) Rock properties of Berea sandstone, Baker dolomite, and Indiana limestone. Paper SPE 21044 
Proceedings of the SPE International Symposium on Oil filed Chemistry held in Anaheim, California, USA.

11. Coenen J, Tchouparova E, Jing X (2004) Measurement parameters and resolution aspects of micro X-ray tomography for advanced core analysis. Proceedings of International Symposium of the Society of Core Analysts Abu Dhabi UAE.

12. Dong Hu, Touati Mustafa, Blunt, Martin J (2007) Pore network modeling: Analysis of pore size distribution of Arabian core samples. Society of Petroleum Engineers (SPE), Richardson, TX 75083-3836, SPE Middle East Oil and Gas Show and Conference MEOS Proceedings, USA

13. Dvorkin J, Armbruster M, Baldwin C (2008) The future of rock physics: computational methods vs. lab testing. Petroleum Geology 26: 63-68.

14. Elliott JC, Dover SD (1982) X-ray micro-tomography. Journal of Microscopy 126: 211-213.

15. Guan Zl, Xie CJ, Dong H (2009) 3D imaging and visualization technology of micro pore structure in porous media. Geological science and technology information 29(2): 115-121

16. Hou J, LI ZQ Zhang SK (2008) Experiment and simulation study on construction of a three-dimensional network model. Science in China (Series G) 51(11): 1761-1774.

17. Ioannidis MA, Chatzis I, Kwiecien MJ (1999) Computer enhanced core analysis for petrophysical properties. Journal of Canadian Petroleum Technology 38: 18-24.

18. Knackstedt MA, Arns CH, Limaye A (2004) Digital core laboratory: properties of reservoir core derived from 3D images. Proceedings, SPE Asia Pacific Conference p. 29-30.

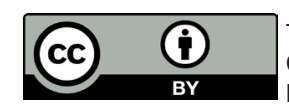

This work is licensed under Creative Commons Attribution 4.0 License

DOI: 10.19080/IMST.2019.01.555565
19. Knackstedt MA, Arns CH, Limaye A, Sakellariou A, Senden TJ, et al. (2004) Digital Core Laboratory: Properties of reservoir core derived from 3D images. SPE 87009. SPE Asia Pacific Conference on Integrated Modelling for Asset Management held in Kuala Lumpur, Malaysia.

20. Okabe H, Blunt MJ (2005) Pore space reconstruction using multiple-point statistics. Journal of Petroleum Science and Engineering 46(1-2): 121-137.

21. Saadatfar M, Turner ML, Arns CH, Averdunk H, Senden TJ, et al. (2005) Rock fabric and texture from digital core analysis. Proceedings of SPWLA 46th Annual Logging Symposium, New Orleans Louisiana United States.

22. She M, Shou JF, Zhen XP (2011) 3D High Resolution Reservoir Characterization Technique Based on CT Imaging and Application. Xinjiang petroleum geology 32(6): 664-666.

23. Zhang TS, Yang Y, Gong QS (2014) Characteristics and mechanisms of the micro-pores in the early Paleozoic Marine Shale. Southern Sichuan Basin. Acta Geologica Sinica 88(9): 1728-1740.

24. Lawrence M, Jiang Y (2017) Porosity, pore size distribution, micro-structure Bio-aggregates Based Building Materials. Springer Dordrecht p. 39-71.

25. Ren X, Li A, Fu S (2019) Influence of micro-pore structure in tight sandstone reservoir on the seepage and water-drive producing mechanism-a case study from Chang 6 reservoir in Huaqing area of Ordos basin. Energy Science \& Engineering.

\section{Your next submission with Juniper Publishers} will reach you the below assets

- Quality Editorial service

- Swift Peer Review

- Reprints availability

- E-prints Service

- Manuscript Podcast for convenient understanding

- Global attainment for your research

- Manuscript accessibility in different formats

(Pdf, E-pub, Full Text, Audio)

- Unceasing customer service

Track the below URL for one-step submission https://juniperpublishers.com/online-submission.php 